\title{
Pengaruh Kepemilikan Publik, NPM, Pertumbuhan Perusahaan, dan Solvabilitas terhadap Pengungkapan CSR pada Perusahaan Infrastruktur
}

\author{
Deasy Arisandy Aruan ${ }^{1 *}$, Veronica $^{2}$, Celine Liandy $^{3}$, Debby Christina ${ }^{4}$, Fanny $^{5}$ \\ 1,2,3,4,5) Universitas Prima Indonesia \\ deasy.aruan@gmail.com ${ }^{1 *}$, veroangkasa2107@gmail.com ${ }^{2}$,celineliandy2000@ gmail.com ${ }^{3}$, \\ debbychristina02@gmail.com ${ }^{4}$, fannyfanhuang@gmail.com ${ }^{5}$
}

*Penulis Korespondensi

Diajukan : 5 Juni 2021

Disetujui : 29 Juni 2021

Dipublikasi : 5 Agustus 2021

\begin{abstract}
This research's purposeisto determine the impactof Public Ownership, Net Profit Margin, Company Growth, and Solvency on Corporate Social Responsibility Disclosures. Thisresearchused a quantitative method and Collection Technique is a documentation technique. The population in this research is includes 82 Infrastructure Companies listed on the Indonesia Stock Exchange for the 2015-2019 period. With a sample of 25 Infrastructure companies listed on the Indonesia Stock Exchange for the 2015-2019 period. The sampling technique in this research is porpusive sampling. The data used in this research is secondary data taken from www.idx.co.id. This research uses multiple linear regression analysis model. The results show that Public Ownership, Net Profit Margin and Company Growth partially had no significant impact on Corporate Social Responsibility Disclosure. Meanwhile, Solvency has a significant positive impact on Corporate Social Responsibility Disclosure. According to simulation, Public Ownership, NPM, Company Growth, and Solvency have no significant impact on Corporate Social Responsibility Disclosure. Testing the analysis of the coefficient of determination shows the results of the adjusted $R$ square value in the coefficient of determination test is $2.6 \%$, where the remaining $97.4 \%$ is influenced by other variables such as deferred exploration and development costs, media disclosure, Leverage, and others.It Indicates thatindependent variables in this research are not sufficiently influential on CSR disclosure because there are still many other variables that have a major influence on CSR Disclosure.
\end{abstract}

Keywords : Corporate Social Responsibility Disclosure; Firm Growth; NPM; Public Ownership; Solvency.

\section{Latar Belakang}

\section{PENDAHULUAN}

Keadaan pembangunan infrastruktur suatu negara merupakan faktor penting yang harus diperhatikan. Ketika keadaan infrastruktur suatu negara lemah, maka perekonomian negara tersebut tidak berjalan secara efisien.Dapat dikatakan perusahaan infrastruktur berperan penting dalam pembangunan infrastruktur sehingga, banyak investor yang mulai tertarik untuk berinvestasi pada perusahaan infrastruktur.Oleh karena itu, perusahaan infrastruktur seharusnya memberikan informasi secara lengkap dan akurat kepada para investor.Terutama pada pengungkapan Corporate Social Responsibility.Sering kali para perusahaan melakukan tanggung jawab sosial tetapi tidak diungkapkan secara luas.Padahal, Corporate Social Responsibility merupakan salah satu hal yang dilihat oleh investor dalam menentukan keputusan.

Salah satu perusahaan infrastruktur yang terlilit kasus CSR adalah PT. Telekomunikasi Indonesia Tbk (PT.Telkom). Pada tahun 2018, PT. Telkom ini mengalami penurunan pada tingkat kepuasan konsumen terhadap layanan yang diberikan oleh PT. Telkom. Salah satu faktor terjadinya penurunan tingkat kepuasan konsumen adalah penerapan program tanggung jawab sosial 
perusahaan yang belum optimal. Dan dari data penelitian ini, pada tahun 2018, PT Telkom mengalami penurunan dalam penerapan program CSR nya. Tingkat kepuasan adalah salah satu bagian dari $C S R$. Oleh karena itu penerapan $C S R$ dalam sebuah perusahaan sangat lah penting.

Berikut ini adalah fenomena dalam penelitian ini yang diambil dari laporan keuangan perusahaan yang diterbitkan pada Bursa Efek Indonesia.

Tabel 1. Tabel Fenomena Perusahaan Infrastruktur

\begin{tabular}{|c|c|c|c|c|c|c|c|c|}
\hline $\begin{array}{l}\mathrm{N} \\
\mathrm{o}\end{array}$ & & Nama Emiten & $\begin{array}{c}\text { Tahu } \\
\mathrm{n}\end{array}$ & $C S R$ & $N P M$ & $\begin{array}{c}\text { Pertumbuhan } \\
\text { Perusahaan }\end{array}$ & $\begin{array}{l}\text { Solvab } \\
\text { ilitas }\end{array}$ & $\begin{array}{c}\text { Kepemilikan } \\
\text { Publik } \\
\end{array}$ \\
\hline \multirow{5}{*}{1} & \multirow{5}{*}{$\begin{array}{l}\text { KO } \\
\text { PI }\end{array}$} & \multirow{5}{*}{$\begin{array}{l}\text { PT. MITRA ENERGI } \\
\text { PERSADATBK }\end{array}$} & 2015 & 0.1319 & 0.0881 & 0.3521 & 0.3576 & 0.1099 \\
\hline & & & 2016 & 0.0989 & 0.1056 & -0.0733 & 0.2481 & 0.0726 \\
\hline & & & 2017 & 0.1538 & 0.0055 & 0.0571 & 0.1805 & 0.0724 \\
\hline & & & 2018 & 0.1538 & -0.6125 & -0.5721 & 0.4549 & 0.1155 \\
\hline & & & 2019 & 0.1209 & 0.0362 & 1.2597 & 0.4178 & 0.1203 \\
\hline \multirow{5}{*}{2} & \multirow{5}{*}{$\begin{array}{l}\text { TL } \\
\text { KM }\end{array}$} & \multirow{5}{*}{$\begin{array}{l}\text { PT. TELKOM } \\
\text { INDONESIATBK }\end{array}$} & 2015 & 0.5275 & 0.2275 & 0.1424 & 0.4378 & 0.3812 \\
\hline & & & 2016 & 0.5055 & 0.2508 & 0.1353 & 0.4124 & 0.4013 \\
\hline & & & 2017 & 0.5055 & 0.2550 & 0.1025 & 0.4351 & 0.4105 \\
\hline & & & 2018 & 0.3846 & 0.2063 & 0.0197 & 0.4311 & 0.4291 \\
\hline & & & 2019 & 0.5165 & 0.2035 & 0.0366 & 0.4700 & 0.4326 \\
\hline \multirow{5}{*}{3} & \multirow{5}{*}{$\begin{array}{l}\mathrm{CM} \\
\mathrm{NP}\end{array}$} & \multirow{5}{*}{$\begin{array}{l}\text { PT. CITRA MARGA } \\
\text { NUSAPHALA } \\
\text { PERSADATBK }\end{array}$} & 2015 & 0.0659 & 0.2975 & -0.2473 & 0.3257 & 0.2539 \\
\hline & & & 2016 & 0.1319 & 0.2201 & 0.5162 & 0.4100 & 0.2389 \\
\hline & & & 2017 & 0.1429 & 0.2384 & 0.2583 & 0.4795 & 0.2351 \\
\hline & & & 2018 & 0.1648 & 0.1912 & 0.3146 & 0.4780 & 0.3898 \\
\hline & & & 2019 & 0.1538 & 0.1955 & -0.0767 & 0.4877 & 0.3898 \\
\hline
\end{tabular}

Dari data di atas, pada tahun 2018-2019NPM dan pertumbuhan perusahaan PT. Mitra Energi Persada kenaikan mengalami sebesar 0.6487 dan 1.8318. Sedangkan CSR mengalami penurunan sebesar 0.0329. PT. Citra Marga Nusaphala Persada terjadi kenaikan Solvabilitas pada tahun 20182019 sebesar 0.0097. Sedangkan CSR mengalami penurunan sebesar 0.011. Hal ini dapat disimpulkan bahwa hasil dari tabel fenomena ini bertentangan dengan teori yang digunakan oleh penelitian ini.

\section{Tujuan Penelitian}

Tujuan dalam penelitian ini adalah untuk mengetahui dan menganalisa pengaruh Kepemilikan Publik terhadap Pengungkapan CSR pada perusahaan Infrastruktur periode 2015-2019, pengaruh pengaruh NPM terhadap Pengungkapan CSR pada perusahaan Infrastruktur periode 2015-2019, pengaruh Pertumbuhan Perusahaan terhadap Pengungkapan CSR pada perusahaan Infrastruktur periode 2015-2019, pengaruh Solvabilitas terhadap Pengungkapan CSR pada perusahaan Infrastruktur periode 2015-2019, dan pengaruh Kepemilikan Publik, NPM, Pertumbuhan Perusahaan dan Solvabilitas secara simultan terhadap Pengungkapan CSR pada perusahaan Infrastruktur periode 2015-2019.

\section{Originalitas Penelitian}

Penelitian ini dikembangkan dari penelitian sebelumnya yaitu dari penelitian Erawati \& Herlina (2021). Adapun originalitas dalam penelitian ini adalah : 
Tabel 2. Tabel Originalitas Penelitian

\begin{tabular}{|c|c|c|c|}
\hline $\begin{array}{l}\text { Nama Peneliti,Tahun } \\
\text { dan Judul Peneliti }\end{array}$ & Persamaan & Perbedaan & $\begin{array}{l}\text { Originalitas } \\
\text { Penelitian }\end{array}$ \\
\hline $\begin{array}{l}\text { (Erawati \& Herlina, } \\
\text { 2021).Pengaruh Dewan } \\
\text { Komisaris, Profitabilitas, } \\
\text { Kepemilikan Saham } \\
\text { Publik, dan Kepemilikan } \\
\text { Manajerial terhadap } \\
\text { Pengungkapan Corporate } \\
\text { Social Responsibility pada } \\
\text { Perusahaan Manufaktur } \\
\text { sektor Industri Barang } \\
\text { Konsumsi yang terdaftar di } \\
\text { BEI tahun 2015-2019. }\end{array}$ & $\begin{array}{l}\text { Variabel } \\
\text { Independen } \\
\text { menggunakan } \\
\text { Kepemilikan Publik } \\
\text { dan Variabel } \\
\text { Dependen } \\
\text { menggunakan } \\
\text { Pengungkapan } \\
\text { Corporate Social } \\
\text { Responsibility pada } \\
\text { periode 2015-2019. }\end{array}$ & 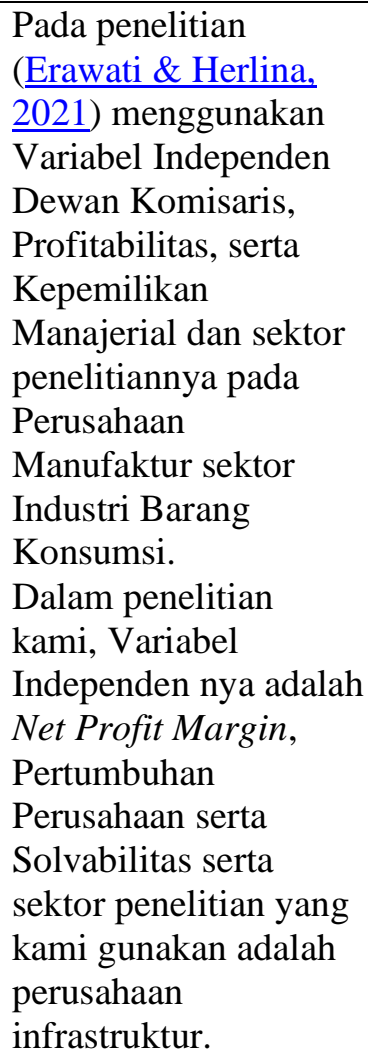 & $\begin{array}{l}\text { Mengganti } \\
\text { beberapa } \\
\text { Variabel } \\
\text { Independen } \\
\text { Dewan } \\
\text { Komisaris, } \\
\text { Profitabilitas, } \\
\text { serta } \\
\text { Kepemilikan } \\
\text { Manajerial } \\
\text { menjadi Net } \\
\text { Profit Margin, } \\
\text { Pertumbuhan } \\
\text { Perusahaan, dan } \\
\text { Solvabilitas serta } \\
\text { sektor penelitian } \\
\text { yang berbeda. }\end{array}$ \\
\hline
\end{tabular}

\section{Penelitian Terdahulu}

\section{STUDI LITERATUR}

Adapun penelitian terdahulu sebelum penelitian ini adalah :

1. Erawati \& Herlina, 2021 dengan judul Pengaruh Dewan Komisaris, Profitabilitas, Kepemilikan Saham Publik, dan Kepemilikan Manajerial terhadap Pengungkapan Corporate Social Responsibility pada Perusahaan Manufaktur sektor Industri Barang Konsumsi yang terdaftar di BEI tahun 2015-2019.

Metode penelitian : Teknik pengambilan data menggunakan analisis regresi berganda.

Hasil Penelitian : Variabel Profitabilitas, Kepemilikan Manajerial tidak memiliki pengaruh terhadap Pengungkapan CSR, Variabel Dewan Komisaris, Kepemilikan Saham Publik memiliki pengaruh positif terhadap Pengungkapan $C S R$.

2. Irhami \& Diana, 2020 dengan judul Pengaruh Struktur Kepemilikan, Ukuran Perusahaan, Kinerja Keuangan, dan Pertumbuhan Perusahaan terhadap Pengungkapan Corporate Social Responsibility (Studi Empiris pada Perusahaan Manufaktur yang tercatat di Bursa Efek Indonesia tahun 2016-2018).

Metode Penelitian : Teknik pengambilan data menggunakan analisis regresi berganda.

Hasil Penelitian : Variabel Struktur Kepemilikan, Ukuran Perusahaan, dan Pertumbuhan Perusahaan tidak memiliki pengaruh terhadap Pengungkapan CSR, Variabel Kinerja Keuangan memiliki pengaruh positif signifikan terhadap Pengungkapan $C S R$.

3. Suryati, 2017 dengan judul Analisis Pengaruh Ukuran Perusahaan, Profitabilitas, Ukuran Dewan Komisaris, Likuiditas, dan Solvabilitas terhadap Pengungkapan Tanggung Jawab Sosial Perusahaan (Studi Kasus pada Bank Umum Syariah di Indonesia Tahun 2012-2016).

Metode Penelitian :Teknik pengambilan data menggunakan analisis regresi berganda.

Hasil Penelitian : Variabel Ukuran Dewan Komisaris, Likuiditas berpengaruh negatif dan tidak signifikan terhadapPengungkapan CSR, Variabel Ukuran Perusahaan dan Solvabilitas memiliki 
pengaruh positif signifikan terhadap Pengungkapan $C S R$, Variabel Profitabilitas memiliki pengaruh Negatif signifikan terhadap Pengungkapan CSR.

\section{Landasan Teori \\ Grand Theory}

Pada penelitian ini, teori utama yang digunakan adalah Teori Legitimasi. Teori ini berupa kontrak sosial yang mengatakan bahwa setiap perusahaan harus mampu dalam meyakinkan masyarakat bahwa kegiatan dan kinerja perusahaan sejalan dan sesuai dengan tujuan masyarakat. Sehingga dapat memberikan pola pikir dan keyakinan bahwa kegiatan operasional perusahaan dapat bermanfaat bagi masyarakat. Selain itu, penelitian ini juga menggunakan teori stakeholder yang berpandangan bahwa perusahaan tidak hanya mempunyai kewajiban kepada para pemegang saham, tetapi juga mempunyai kewajiban terhadap pemangku kepentingan. Hal ini tidak lepas dari kenyataan bahwa perusahaan tidak dapat berlangsung tanpa bantuan dari berbagai pihak.

\section{Pengungkapan Corporate Social Responsibility}

Corporate Social Responsibilityadalah kewajiban sosial perusahaan terhadap masyarakat dan pemerintah sebagai dampak dari ekspansi bisnis yang dimungkinkan telah mengganggu keseimbangan lingkungan dan sosial masyarakat dimana mereka menjalankan aktivitasnya, (Said, 2018).Pada penelitian ini, penilaian pengungkapan CSRdiukur dengan melihat pedoman dari standards GRI terbaru tahun 2019 dengan kriteria yang dibagi menjadi 3 kategori dampak aktivitas perusahaan yaitu ekonomi, lingkungan dan sosial.

\section{Kepemilikan Publik}

$$
\operatorname{CSRID}=\frac{\sum \mathrm{Xij}_{\mathrm{ij}}}{\mathrm{nj}}
$$

Menurut (Rivandi, 2021), kepemilikan publik adalah kepemilikan saham yang dimiliki oleh pihak investor individual diluar manajemen yang tidak memiliki hubungan istimewa dengan perusahaan. Kepemilikan publik menggambarkan tingkat kepemilikan oleh perusahaan oleh masyarakat publik. Besarnya kepemilikan saham individual ini biasanya dibawah 5\%, sehingga investor tidak memiliki kendali atas perusahaan, oleh karena itu investor publik memerlukan perlindungan atas saham yang mereka tanam, perlindungan ini dapat berupa pengungkapan informasi keuangan dan non-keuangan pada perusahaan tahunan yang berguna dalam pengambilan keputusan

$$
\text { Kepemilikan Publik }=\frac{\text { Jumlah Saham Publik }}{\text { Jumlah Saham Beredar }}(2)
$$

\section{Net Profit Margin}

Menurut (Koloay, Montolalu, \& Mangindaan, 2018), NPM merupakan hubungan antara laba bersih setelah pajak dengan penjualan. Salah satu tujuan utama didirikannya perusahaan adalah mendapatkan profit untuk kemakmuran pemegang saham. Untuk mencapai profit yang diinginkan, perusahaan akan berusaha untuk meningkatkan kegiatan operasionalnya. Kegiatan operasional perusahaan pasti menimbulkan dampak bagi sosial dan lingkungan. Diharapkan semakin tinggi profit yang didapatkan, maka semakin banyak pula kegiatan CSR yang dilakukan oleh perusahaan.

$$
\text { NPM }=\frac{\text { Laba Bersih }}{\text { Penjualan Bersih }}
$$

\section{Pertumbuhan Perusahaan}

Menurut(Kasmir, 2018), Rasio pertumbuhan merupakan rasio yang menggambarkan kemampuan perusahaan mempertahankan posisi ekonomi ditengah pertumbuhan ekonomi dan usahanya. Pertumbuhan perusahaan merupakan salah satu pertimbangan para investor dalam menanamkan investasinya. Perusahaan yang memiliki kesempatan tumbuh yang tinggi diharapkan akan memberikan profitabilitas yang tinggi di masa depan, diharapkan laba lebih persisten, sehingga investor akan tertarik untuk berinvestasi di perusahaan tersebut.

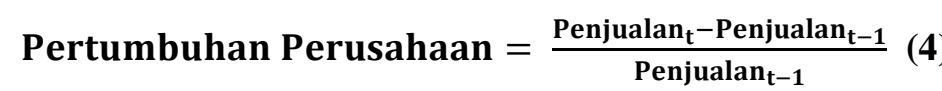




\section{Solvabilitas}

Menurut (Sadewo, 2019), Rasio solvabilitas atau adalah jenis rasio yang digunakan untuk mengukur aktiva perusahaan yang dibiayai dengan utang. Artinya seberapa besar beban utang yang telah di tanggung perusahaan dibanding dengan aktivanya dalam arti yangluas bisa dikatakan bahwa rasio solvabilitas inidipergunakan untuk mengukur kemampuan suatu perusahaan untuk membayar kewajibanya baik itu jangka pendek ataupun jangkapanjang apabila perusahaan telah dibubarkan.Jika aset perusahaan cukup untuk menutup semua kewajiban pendek dan jangka panjangnya, maka perusahaan tersebut dapat dikatakan solvabel. Semakin tinggi solvabilitas suatu perusahaan, maka akan semakin luas pengungkapan yang dilakukan oleh perusahaan.

$$
\text { DAR }=\frac{\text { Total Hutang }}{\text { Total Aset }} \text { (5) }
$$

\section{Rumusan Hipotesis}

1. Kepemilikan Publik berpengaruh secara parsial terhadap Pengungkapan CSR.

2. $N P M$ berpengaruh secara parsial terhadap Pengungkapan CSR.

3. Pertumbuhan Perusahaan berpengaruh secara parsial terhadap Pengungkapan CSR.

4. Solvabilitas berpengaruh secara parsial terhadap Pengungkapan CSR.

5. Kepemilikian Publik, NPM, Pertumbuhan Perusahaan dan Solvabilitas berpengaruh secara simultan terhadap Pengungkapan CSR.

\section{Populasi dan Sampel Penelitian}

\section{METODE}

Dalam penelitian ini populasi diambil dari perusahaan infrastruktur yang terdaftar di Bursa Efek Indonesia tahun 2015-2019. Dimana jumlah populasi dalam penelitian ini sebanyak 82 perusahaan.Sedangkan sampel penelitian ini diambil menggunakan metode purposive sampling. Menurut Sugiono (2012:122), purposive sampling adalah teknik penentuan sampel dengan pertimbangan tertentu. Berikut ini adalah kriteria dalam pengambilan sampel:

1.Perusahaan infrastruktur yang terdaftar di BEI pada tahun 2015-2019

2.Perusahaan infrastruktur yang data laporan tahunannya tersedia di BEI pada tahun 2015-2019

3.Perusahaan infrastruktur yang annual reportnya tersedia di BEI pada tahun 2015-2019

4.Perusahaan infrastruktur yang laporan keuangannya dalam bentuk Rupiah.

5.Perusahaan Infrastrukrur yang lengkap pada variabel penelitian.

Tabel 4.Kriteria Pengambilan Sampel

\begin{tabular}{|c|c|c|}
\hline No & Kriteria & Jumlah \\
\hline 1 & Perusahaan Infrastruktur yang terdaftar di BEI pada tahun 2015-2019. & 82 \\
\hline 2 & $\begin{array}{l}\text { Perusahaan Infrastruktur yang data laporan tahunannya tidak tersedia di BEI } \\
\text { pada tahun } 2015-2019\end{array}$ & $(20)$ \\
\hline 3 & $\begin{array}{l}\text { Perusahaan Infrastruktur yang annual reportnya tidak tersedia di BEI pada } \\
\text { tahun 2015-2019 }\end{array}$ & (18) \\
\hline 4 & $\begin{array}{l}\text { Perusahaan Infrastruktur yang laporan keuangannya tidak dalam bentuk } \\
\text { Rupiah }\end{array}$ & (17) \\
\hline 5 & Perusahaan Infrastruktur yang tidak lengkap pada variabel penelitian & (2) \\
\hline & Total & 25 \\
\hline & Jumlah sampel di kali 5 tahun $(25$ x 5$)$ & 125 \\
\hline
\end{tabular}

\section{Jenis dan Sumber Data}

Data yang digunakan dalam penelitian ini adalah data sekunder. Data sekunder ini diperoleh dari situs resmi Bursa Efek Indonesia yaitu www.idx.co.id. Data sekunder ini berupa laporan keuangan dan laporan tahunan perusahaan infrastruktur periode 2015-2019.

\section{Teknik Pengumpulan Data}


Teknik dalam penelitian ini adalah teknik dokumentasi. Teknik dokumentasi dalam penelitian ini dilakukan dengan cara menganalisa laporan keuangan dan laporan tahunan perusahaan infrastruktur pada periode 2015-2019 yang diperoleh dari website resmi Bursa Efek Indonesia.

\section{Metode Analisa Data}

Metode analisa yang digunakan dalam penelitian ini adalah analisa statistik deskriptif dan analisa regresi linear berganda. Analisa statistik deskriptif digunakan dalam penelitian ini untuk mengambarkan data yang telah terkumpul dalam penelitian ini. Sedangkan analisa regresi linear berganda meliputi uji asumsi klasik dan uji koefisien determinasi. Uji asumsi klasik dalam penelitian ini digunakan untuk memastikan apakah model dalam penelitian ini telah sesuai dengan asas BLUE (Best Linear Unbiased Estimator). Dan uji koefisien determinasi dalam penelitian ini bertujuan untuk melihat seberapa besar variabel independen $(\mathrm{X})$ mampu menjelaskan variasi variabel dependen $(\mathrm{Y})$.

\section{Statistik Deskriptif}

\section{HASIL}

Data statistik deskriptif pada penelitian ini adalah 125 data observasi dari total sampel perusahaan berjumlah 25 dengan periode penelitian 5 tahun (2015-2019). Pada penelitian ini dapat kita lihat hasil uji statistik deskriptif dari tabel berikut:

Tabel 5. Statistik Deskriptif

\begin{tabular}{|l|c|r|r|r|r|}
\hline & \multicolumn{1}{|c|}{ N } & \multicolumn{1}{c|}{ Minimum } & Maximum & \multicolumn{1}{c|}{ Mean } & Std. Deviation \\
\hline Kepemilikan Publik & 125 &, 0108980 & 4,8997500 &, 468818620 &, 9180609021 \\
\hline Net Profit Margin & 125 & $-3,8593418$ &, 7720463 &,- 072270605 &, 5956635278 \\
\hline Pertumbuhan Perusahaan & 125 &,- 8192436 & 4,0329284 &, 122424328 &, 4626133480 \\
\hline Solvabilitas & 125 &, 1008003 & 1,9474137 &, 565643317 &, 2775885503 \\
\hline CSR & 125 &, 0549451 &, 6373626 &, 236483517 &, 1413466899 \\
\hline Valid N (listwise) & 125 & & & & \\
\hline
\end{tabular}

Berdasarkan hasil perhitungan dari tabel di atas, dapat diketahui bahwa $n$ atau jumlah data pada setiap variabel yaitu 125 yang berasal dari perusahaan infrastuktur yang terdaftar di BEI tahun 2015-2019. Variabel kepemilikan publik memiliki nilai terendah 0,01 dan nilai tertinggi 4,89 dengan nilai rata-ratanya sebesar 0,46 dan standar deviasinya (tingkat sebaran datanya) sebesar 0,91. Variabel Net Profit Margin memiliki nilai terendah -3,85 dan nilai tertinggi sebesar 0,77 dengan nilai rata-ratanya sebesar $-0,07$ dan tingkat sebaran datanya sebesar 0,59 . Variabel pertumbuhan perusahaan memiliki nilai terendah $-0,81$ dan nilai tertinggi 4,03 dengan nilai rataratanya sebesar 0,12 dengan standar deviasinya sebesar 0,46. Variabel Solvabilitas memiliki nilai terendah 0,10 dan nilai tertinggi 1,94 dengan nilai rata-ratanya 0,56 dengan standar deviasinya 0,27 . Variabel CSRmemiliki nilai terendah 0,05 dan nilai tertinggi 0,63 dengan nilai rata-ratanya sebesar 0,23 dan tingkat sebaran datanya 0,14 .

\section{Uji Asumsi Klasik}

Tabel 6. Kesimpualan dari Uji Asumsi Klasik dalam Penelitian Ini

\begin{tabular}{|l|l|l|l|l|}
\hline Uji Asumsi & Pengujuan & Syarat & Hasil & Kesimpulan \\
\hline Uji Normalitas & $\begin{array}{l}\text { Kolmogorov } \\
\text { Smirnov }\end{array}$ & $\begin{array}{l}\text { Nilai } \\
\text { Asympsig }(2- \\
\text { tailed) } 0.05\end{array}$ & 0,068 & $\begin{array}{l}\text { Data berdistribusi } \\
\text { dengan normal. }\end{array}$ \\
\hline Uji & Variance & Nilai & Nilai Tolerance & Data bebas dari \\
Multikolinearitas & Inflation Factor & Tolerance $>$ & 0,$727 ; 0,725 ;$ & gejala \\
& (VIF) & 0,100 dan & 0,$949 ; 0,757$. & Nilikolinearitas \\
& & nilai VIF $<$ & Nilai 1,375; & \\
& & 10,00 & 1,$380 ; 1,054 ;$ & \\
& & & 1,322 & \\
\hline
\end{tabular}


Owner: Riset \& Jurnal Akuntansi

e-ISSN : 2548-9224|p-ISSN : 2548-7507

Volume 5 Nomor 2, Agustus 2021

DOI : https://doi.org/10.33395/owner.v5i2.455

\begin{tabular}{|l|l|l|l|l|}
\hline Uji Autokorelasi & Run Test & $\begin{array}{l}\text { Nilai Asymp } \\
\text { Sig (2-tailed) } \\
>0,05\end{array}$ & 0,127 & $\begin{array}{l}\text { Data bebas dari } \\
\text { gejala autokorelasi }\end{array}$ \\
\hline $\begin{array}{l}\text { Uji } \\
\text { Heterokedasitas }\end{array}$ & Glejser & $\begin{array}{l}\text { Nilai Sig per } \\
\text { variabel }> \\
0,05\end{array}$ & $\begin{array}{l}0,996 ; 0,054 ; \\
0,054 ; 0,066\end{array}$ & $\begin{array}{l}\text { Data bebas dari } \\
\text { gejala } \\
\text { heterokedasitas }\end{array}$ \\
\hline
\end{tabular}

\section{Hasil Analisis Data Penelitian}

Tabel 7. Uji Goodness of Fit (GoF)

\begin{tabular}{|l|c|l|c|c|}
\hline Adjusted R Square/Koefisien Determinasi &, 026 & \multicolumn{5}{l|}{} \\
\hline F.Stat/Anova/Uji Simulan/Uji Serempak & 1,814 & Sig &, $130^{\mathrm{b}}$ & \\
\hline \multicolumn{1}{|c|}{ Uji Parsial/Uji T/ Uji Hipotesis } & B & Std.Error & t & Sig \\
\hline (Constant) &, 178 &, 031 & 5,774 &, 000 \\
\hline Kepemilikan Publik &,- 002 &, 016 &,- 113 &, 910 \\
\hline Net Profit Margin &, 048 &, 025 & 1,952 &, 053 \\
\hline Pertumbuhan Perusahaan &,- 019 &, 028 &,- 688 &, 493 \\
\hline Solvabilitas &, 115 &, 052 & 2,221 &, 028 \\
\hline
\end{tabular}

Dari tabel 7 diatas dapat dipaparkan model regresi liner berganda dalam penelitian ini adalah sebagai berikut

\section{Y = 0,178 - 0,002 Kepemilikan Publik + 0,048 NPM - 0,019 Pertumbuhan Perusahaan + 0.115 Solvabilitas}

1. Angka konstanta sebesar 0,178 menyatakan bahwa jika nilai Kepemilikan Publik, $N P M$, Pertumbuhan Perusahaan, dan Solvabilitas sama dengan nol, maka luas pengungkapan CSRperusahaan infrastruktur yang terdaftar di BEI periode 2015-2019 mengalami peningkatan sebesar 0,178 .

2. Jika koefisien regresi variabel Kepemilikan Publik sebesar $-0,002$ nilai tersebut berarti bahwa setiap peningkatan Kepemilikan Publik sebesar satu poin, maka luas pengungkapan CSRakan mengalami penurunan sebesar 0,002.

3. Jika koefisien regresi variabel $N P M$ sebesar 0,048 nilai tersebut berarti bahwa setiap peningkatan NPM sebesar satu poin, maka luas pengungkapan CSR akan mengalami peningkatan sebesar 0,048 .

4. Jika koefisien regresi variabel Pertumbuhan Perusahaan sebesar $-0,019$ nilai tersebut berarti bahwa setiap peningkatan Pertumbuhan Perusahaan sebesar satu poin, maka luas pengungkapan CSRakan mengalami penurunan sebesar 0,019.

5. Jika koefisien regresi variabel Solvabilitas sebesar 0,115 nilai tersebut berarti bahwa setiap peningkatan Solvabilitas sebesar satu poin, maka luas pengungkapan CSRakan mengalami peningkatan sebesar 0,115 .

Berdasarkan tabel di atas, dapat disimpulkan bahwa Uji Koefisien Determinasi (R) menghasilkan nilai 0,026 atau 2,6\%. Dengan demikian variabel dependen CSRdipengaruhi oleh empat variabel bebas yaitu variabel independen yaitu Kepemilikan Publik, NPM, Pertumbuhan Perusahaan dan Solvabilitas sebesar 2,6\% sedangkan sisanya 97,4\% lagi dijelaskan oleh variabel lain seperti biaya eksplorasi dan pengembangan tangguhan, pengungkapan media, Leverage, serta lainnya.

Uji F Simultan yang diperlihatkan pada tabel 7 dalam penelitian ini untuk menunjukkan apakah semua variabel independen atau bebas yang dimasukkan dalam model mempunyai pengaruh secara bersama-sama terhadap variabel dependen / terikat jika nilai Sig. $<0,05$. Dari hasil penelitian, nilai signifikannya 0,130 yang artinya lebih besar dari 0,05. Maka kesimpulan dari uji simultan $\mathrm{F}$ ini adalah variabel $\mathrm{X}_{1}, \mathrm{X}_{2}, \mathrm{X}_{3}$ dan $\mathrm{X}_{4}$ tidak berpengaruh secara signifikan terhadap $\mathrm{Y}$. Serta dapat di perkuat dengan menghitung nilai hitung dan tabel. Rumus mencari $\mathrm{f}$ tabel $=(\mathrm{k} ; \mathrm{n}-\mathrm{k})=(4 ; 125-4)=$ $(4 ; 121)=2,45$. Jadi $f_{\text {hitung }}>f_{\text {tabel }}=1.814<2,55$. Maka kesimpulan uji $\mathrm{f}$ simultan menurut 
perbandingan nilai $\mathrm{f}$ tabel dan $\mathrm{f}$ hitung: $\mathrm{X}_{1}, \mathrm{X}_{2}, \mathrm{X}_{3}, \mathrm{X}_{4}$ Secara simultan tidak berpengaruh terhadap Y.

Berdasarkan tabel 7 diatas hasil uji T Parsial pada penelitian ini menunjukkan hasil sebagai berikut:

Besar $\mathrm{t}$ tabel $=(\mathrm{alfa} / 2 ; \mathrm{n}-\mathrm{k}-1)=(0.05 / 2 ; 125-4-1)=(0,025 ; 120)=1,97993$ (distribusi nilai $\mathrm{t})$.

Maka hasil perbandigan antara $t$ tabel dengan $t$ hitung adalah :

1. Berdasarkan hasil uji $\mathrm{T}$ dalam penelitian ini menunjukkan bahwa variabel Kepemilikan Publik memiliki nilai $t_{\text {hitung }}$ sebesar $-0,113$ dan $t_{\text {tabel }}$ sebesar $-1,979$ dengan nilai $\mathrm{df}=120(125-4-1$ $=120)$ sehingga nilai $t_{\text {hitung }}(-0,113)>t_{\text {tabel }}(-1,979)$, dengan nilai signifikan untuk variabel 0,910 dimana Kepemilikan Publik nilainya lebih besar daripada tingkat signifikan 0,05 (0,910 > 0,05). Maka dapat disimpulkan bahwa Kepemilikan Publik secara parsial tidak berpengaruh signifikan terhadap pengungkapan CSR perusahaan infrastruktur yang terdaftar di BEI tahun 2015-2019.

2. Berdasarkan hasil uji $\mathrm{T}$ dalam penelitian ini menunjukkan bahwa variabel $N P M$ memiliki nilai $t_{\text {hitung }}$ sebesar 1,952 dan $t_{\text {tabel }}$ sebesar 1,979 dengan nilai $\mathrm{df}=120(125-4-1=120)$ sehingga nilai $t_{\text {hitung }}(1,952)<\mathrm{t}_{\text {tabel }}(1,979)$, dengan nilai signifikan untuk variabel 0,053 dimana $N P M$ nilainya lebih besar daripada tingkat signifikan $0,05(0,0.53>0,05)$. Maka dapat disimpulkan bahwa NPM secara parsial tidak berpengaruh signifikan terhadap pengungkapan CSR perusahaan infrastruktur yang terdaftar di BEI tahun 2015-2019.

3. Berdasarkan hasil uji $\mathrm{T}$ dalam penelitian ini menunjukkan bahwa variabel Pertumbuhan Perusahaan memiliki nilai $t_{\text {hitung }}$ sebesar $-0,688$ dan $t_{\text {tabel }}$ sebesar $-1,979$ dengan nilai $\mathrm{df}=120$ $(125-4-1=120)$ sehingga nilai $t_{\text {hitung }}(-0,688)>t_{\text {tabel }}(-1,979)$, dengan nilai signifikan untuk variabel 0,493 dimana Pertumbuhan Perusahaan nilainya lebih besar daripada tingkat signifikan 0,05 $(0,493>0,05)$. Maka dapat disimpulkan bahwa Pertumbuhan Perusahaan secara parsial tidak berpengaruh signifikan terhadap pengungkapan CSR perusahaan infrastruktur yang terdaftar di BEI tahun 2015-2019.

4. Berdasarkan hasil uji $\mathrm{T}$ dalam penelitian ini menunjukkan bahwa variabel $D A R$ memiliki nilai $\mathrm{t}_{\text {hitung }}$ sebesar 2,221 dan $\mathrm{t}_{\text {tabel }}$ sebesar 1,979 dengan nilai $\mathrm{df}=120(125-4-1=120)$ sehingga nilai $t_{\text {hitung }}(2,221)>t_{\text {tabel }}(1,979)$, dengan nilai signifikan untuk variabel 0,028 dimana $D A R$ nilainya lebih kecil daripada tingkat signifikan $0,05(0,028<0,05)$. Maka dapat disimpulkan bahwa $D A R$ secara parsial berpengaruh positif signifikan terhadap pengungkapan CSR perusahaan infrastruktur yang terdaftar di BEI tahun 2015-2019.

\section{PEMBAHASAN \\ Pengaruh Kepemilikan Publik $\left(\mathrm{X}_{1}\right)$ terhadap Pengungkapan Corporate Social Responsibility (Y)}

Hasil penelitian menunjukkan Kepemilikan Publik tidak berpengaruh secara signifikan terhadap pengungkapan CSR pada perusahaan infrastruktur yang terdaftar di BEItahun 2015-2019. Hal ini dikarenakan $t_{\text {hitung }}$ memiliki nilai negatif. Hal ini dapat terjadi dikarenakan perusahaan yang dijadikan sampel persentasi kepemilikan publik rata rata $\leq 5 \%$ sehingga Kepemilikan Publik tidak berpengaruh terhadap Pengungkapan CSR. Hasil penelitian ini didukung oleh hasil Indraswari dan

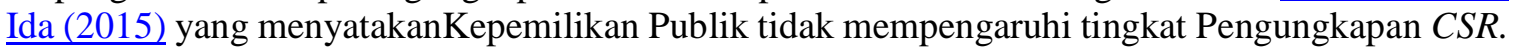
Hasil penelitian ini sejalan dengan teori (Rivandi, 2021) yang menyatakan bahwa tinggi atau rendahnya kepemilikan saham publik dalam perusahaan tidak mempengaruhi dalam pengungkapan CSR.

Pengaruh Net Profit Margin $\left(\mathrm{X}_{2}\right)$ terhadap Pengungkapan Corporate Social Responsibility (Y) Hasil penelitian menunjukan NPM tidak berpengaruh secara signifikan terhadap Pengungkapan CSR pada perusahaan infrastruktur yang terdaftar di BEItahun 2015-2019. Hal ini dikarenakan nilai $t_{\text {hitung }}$ lebih kecil dari $t_{\text {tabel. }}$. Maka dari itu dikatakan bahwa laba perusahaan yang tinggi tidak berarti dapat mempengaruhi Pengungkapan CSR perusahaan. Hasil penelitian ini didukung dengan hasil(Yulianti, 2017)yang menyatakan bahwa NPMtidak berpengaruh signifikan terhadap Pengungkapan CSR. Hasil penelitian ini sejalan dengan teori dari (Nadhifah \&Agustina, 2019) yang 
menyatakan bahwa semakin tinggi laba bersih sebuah perusahaan, bukan berarti perusahaan tersebut melakukan pengungkapan CSR sebanyak mungkin.

\section{Pengaruh Pertumbuhan Perusahaan $\left(\mathrm{X}_{3}\right)$ terhadap Pengungkapan Corporate Social Responsibility (Y)}

Hasil penelitian menunjukan Pertumbuhan Perusahaan tidak berpengaruh secara signifikan terhadap Pengungkapan CSR pada perusahaan infrastruktur yang terdaftar di BEItahun 20152019.Hal ini dikarenakan $t_{\text {hitung }}$ memiliki nilai negatif. Hasil penelitian ini didukung penelitian yang dilakukan oleh(Prasetyo \& Widiasmara, 2019) yang menyatakan pertumbuhan perusahaan tidak berpengaruh terhadap Pengungkapan CSR. Hasil penelitian ini tidak sejalan dengan teori Sari (2017) yang menyatakan bahwa perusahaan yang tinggi pertumbuhan perusahaannya akan mendapatkan banyak perhatian sehingga diperkirakan akan lebih luas dalam Pengungkapan CSR. Namun masih banyak perusahaan yang memiliki pertumbuhan perusahaan yang tinggi tidak melakukan pengungkapan yang lebih luas.

\section{Pengaruh Solvabilitas $\left(\mathrm{X}_{4}\right)$ terhadap Pengungkapan Corporate Social Responsibility (Y)}

Hasil penelitian menunjukan Solvabilitas berpengaruh positif terhadap Pengungkapan CSR pada perusahaan infrastruktur yang terdaftar di BEItahun 2015-2019. Hal ini dikarenakan $t_{\text {hitung }}$ yang lebih besar dari tabel dan nilai sig yang lebih besar dari 0,05. Hal ini dikarenakan rasio solvabilitas yang digunakan untuk memberikan gambaran mengenai struktur modal yang dimiliki perusahaan sehingga dapat dilihat tingkat resiko tak tertagihnya utang perusahaan. Serta untuk mengurangi keraguan para investor terhadap dipenuhi tidaknya hak mereka sebagai kreditor. Oleh karena itu perusahaan dengan rasio solvabilitas mempunyai kewajiban dalam mengungkapkan CSR secara luas.Hasil penelitian ini didukung oleh penelitian yang dilakukan oleh (Wasito, Herwiyanti, \& Kusumastati, 2016) yang menyatakan bahwa variabel solvabilitas berpengaruh terhadap Pengungkapan CSR. Hasil penelitian ini sejalan dengan teori dari(Sadewo, 2019) menyatakan bahwa perusahaan yang memiliki solvabilitas yang tinggi lebih memilih untuk membayar hutang hutangnya ketimbang melakukan pengungkapan $C S R$ yang lebih luas lagi.

\section{KESIMPULAN}

Dalam penelitian ini peneliti mengambil kesimpulan bahwaKepemilikan Publik, Net Profit Margin, dan Pertumbuhan Perusahaan tidak berpengaruh terhadap PengungkapanCorporate Social Responsibility pada Perusahaan Infrastruktur yang terdaftar di BEI pada tahun 2015-2019. Sedangkan Solvabilitas memiliki pengaruh positif signifikan terhadapPengungkapanCorporate Social Responsibility pada Perusahaan Infrastruktur yang terdaftar di BEI pada tahun 2015-2019. Dan Secara simultan variabel Kepemilikan Publik, Net Profit Margin, Pertumbuhan Perusahaan dan Solvabilitas tidak berpengaruh terhadap PengungkapanCorporate Social Responsibility pada Perusahaan Infrastruktur yang terdaftar di BEI pada tahun 2015-2019.

\section{REFERENSI}

Indraswari, G.A.D. \& Astika, I. B. (2015). Pengaruh Profitabilitas, Ukuran Perusahaan, dan Kepemilikan Saham Publik Terhadap Pengungkapan CSR.

Irhami, W., \& Diana, N. (2020). Pengaruh Struktur Kepemilikan, Ukuran Perusahaan, Kinerja Keuangan,dan Pertumbuhan Perusahaan terhadap Pengungkapan Corporate Social Responsibility (Studi Empiris pada Perusahaan Manufaktur yang tercatat di Bursa Efek Indonesia tahun 2016-2018). Fakultas Ekonomi dan Bisnis Universitas Islam Malang Vol. 09 No. 10 Agustus 2020.

Kasmir, K. (2018). Pengantar Manajemen Keuangan Edisi Kedua. Jakarta: Prenadamedia Group. Koloay, N., Montolalu, J., \& Mangindaan, J. V. (2018). Pengaruh Kinerja Keuangan Terhadap Tanggung Jawab Sosial Perusaahaan (Corporate Social Responsibility) pada Perusahaan Tambang yang terdaftar di Bursa Efek Indonesia Periode 2015-2016. Jurnal Administrasi Bisnis Vol. 6 No. 2.

Nadhifah, M., \& Agustina, R. (2019). Pengaruh Net Profit Margin dan Current Ratio terhadap Pengungkapan Tanggung Jawab Sosial Perusahaan Manufaktur Sub Sektor Plastik dan 
Logam. Journal of Finance and Accounting Studies Volume 1 Nomor 1, Pebruari 2019, 63-76.

Prasetyo, A., \& Widiasmara, A. (2019). Pengaruh Firm Size, Profitabilitas, dan Pertumbuhan Perusahaan terhasap CSR sektor Pertambangan Indonesia. SEMINAR INOVASI MANAJEMEN, BISNIS DAN AKUNTANSI I.

Rivandi, M. (2021). Pengaruh Struktur Kepemilikan Terhadap Pengungkapan Corporate Social Responsibility. Jurnal Informasi, Perpajakan, Akuntansi, dan Keuangan Publik Vol 16 No.1 Januari 2021, 21-40.

Sadewo, K. A. (2019). Pengaruh Profitabilitas, Likuiditas, dan Solvabilitas Terhadap Pengungkapan Corporate Social Responsibility pada Perusahaan PT. Indah Logistic Cargo. Surabaya: Sekolah Tinggi Ilmu Ekonomi Indonesia STIESIA Surabaya .

Said, A. L. (2018). Corporate Social Responsibility dalam Perspektif Governance. Yogyakarta: Deepublish.

Sari, N., Munthe, I. L., \& Ratih, A. E. (2017). Pengaruh Return On Asset (ROA), Debt to Equity Ratio (DER), Pertumbuhan Perusahaan dan Ukuran Dewan Komisaris Terhadap Pengungkapan Corporate Social Responsibility pada Perusahaan Manufaktur yang Terdaftar di Bursa Efek Indonesia Periode 2012-2014.

Sugiyono, S. (2012). Metode Penelitian Bisnis. Bandung: Alfabeta.

Suryati, R. (2017). Analisis Pengaruh Ukuran Perusahaan, Profitabilitas, Ukuran Dewan Komisaris, Likuiditas, dan Solvabilitas terhadap Pengungkapan Tanggung Jawab Sosial Perusahaan (Studi Kasus pada Bank Umum Syariah di Indonesia Tahun 2012-2016. Salatiga: IAIN Salatiga.

Wasito, G. A., Herwiyanti, E., \& Kusumastati, W. H. (2016). Pengaruh Corporate Gonvernance, Profitabilitas, Likuiditas dan Solvabilitas Terhadap Corporate Social Responsibility Disclosure. Jurnal Bisnis Dan Akuntansi Vol. 18, No. 1, Juni 2016, 1-10.

Yulianti, E. (2017). Pengaruh Biaya Eksplorasi dan Pengembangan Tangguhan, Debt to Equity Ratio, Return On Asset, Net Profit Margin terhadap Luas Pengungkapan Corporate Social Responsibility pada Perusahaan Pertambangan yang terdaftar di Bursa Efek Indonesia tahun 2012-2014. 